\title{
THUNDER UP THE TAXES!
}

\author{
Kyle Dean \\ Oklahoma City University • Oklahoma City, Oklahoma \\ Russell Evans \\ Oklahoma City University • Oklahoma City, Oklahoma \\ Jonathan Willner \\ Oklahoma City University • Oklahoma City, Oklahoma
}

\section{ABSTRACT}

Oklahoma City taxpayers approved a $1 \%$ sales tax to raise an estimated $\$ 120$ million for improvements to lure the Seattle Supersonics, now the Oklahoma City Thunder. City civic leaders engaged a "Big League City" campaign, touting economic growth, increased business activity and jobs, and better quality of life as reasons to support the initiative. We evaluate the "Big League City" economic claims using local sales tax revenues to estimate the level and growth impacts resulting from the relocation of the now Oklahoma City Thunder. We find no significant relationship between the operation of the franchise and contemporaneous sales tax collections. However, we find a modest positive significant relationship between the presence of the franchise and the year-over-year growth rate of aggregate sales tax collections, providing some support for the amenity "Big League City" argument.

Keywords: Sports, tax revenue

\section{INTRODUCTION}

In 2008 the former Seattle Supersonics of the National Basketball Association (NBA) began the 2008 - 2009 season as the Oklahoma City Thunder. In a wellpublicized move, new owners based in Oklahoma City relocated the franchise to Oklahoma's capital city. As a relocation incentive, Oklahoma City residents agreed to continue a $1 \%$ temporary sales tax to fund improvements to the then "Ford Center" arena and to fund the construction of a new team practice facility. Passed in March of 2008, the tax lasted 15 months and raised just over $\$ 105$ million in revenues to fund the Thunder projects.

According to Forbes' Christopher Helman (2012), the Oklahoma City-based owners purchased the franchise with the promise to remain in Seattle "so long as we are able to negotiate an attractive successor venue and lease arrangement". Following a protracted discussion, the Seattle Legislature failed to approve the 
necessary incentives for new construction and the franchise owner group set the move to Oklahoma City in motion.

Oklahoma City gained experience hosting an NBA franchise, the New Orleans Hornets, after Hurricane Katrina. The city served as the Hornets' temporary host for two seasons (2005-06 and 2006-07). Hosting the Hornets created enthusiasm for the NBA within OKC. The experience provided positive evidence of the city's ability to support an NBA franchise; the announced paid attendance averaged 18,737 per game according to an economic impact study by Bryant and Evans (2007). While citizens hoped to retain the Hornets, their relocation to OKC was temporary and they returned to New Orleans after only two seasons. However, the Hornets experience changed the expectations of OKC residents and signaled to the NBA that OKC was in the market and could support an NBA franchise.

Without support from Seattle taxpayers, the new ownership group decided to move the team after OKC voters approved the extension of an existing \$0.01 (1\%) sales tax to fund arena and practice facility improvements. The sales tax extension was widely supported by local leaders as a means to increase economic activity and create long run growth, in turn making $\mathrm{OKC}$ a desirable place to live and work. OKC voters had previously approved two sales tax initiatives beginning in 1993 aimed at increasing local amenities, the Metropolitan Area Projects (MAPS) and MAPS for Kids. In a supportive "Vote Yes" television advertisement, Mayor Mick Cornett along with two previous mayors, Kirk Humphries and Ron Norick stated “...just like MAPS, improving the Ford Center will grow our economy, help attract even more companies, creating better paying jobs and improving quality of life". Using the tagline "Big League City," the message was clear that local leaders expected a long-run amenity effect from the relocated franchise.

The potential impacts from professional sports franchises may include both contemporaneous impacts on local sales tax collections and long run impacts on local labor markets and business development from the improved local amenity package and quality of life enhancement. We investigate both impact avenues in the body of this paper. The empirical investigation is intentionally limited to Oklahoma City in an effort to identify case-specific fiscal and amenity effects. The relevant literature is reviewed in the next section followed by a discussion of the data and methodology, results, and a conclusion. 


\section{LITERATURE}

The economic benefits of sports franchises are difficult to estimate. Indeed, even obtaining agreement on the term "benefit" is a challenge as evidenced by the multiple approaches for estimation used in the literature. The first best method for determining the net value of public expenditure is to compare total benefits to total costs and estimate the net present value of net benefits for the years of implementation and operation. While the cost of local investment is relatively easy to calculate, benefit calculation requires the estimation of both use and non-use values as well as local growth benefits that may or may not occur due to amenity induced migration. These non-use and growth benefits are at best, difficult to determine and at worst, unknowable. Non-use valuation can be estimated, as seen by Johnson et al (2001), but the problem of determining the appropriate stakeholders still exists.

Haughwout and Inman (2002) and Rappaport (2005) find that the benefits of local amenities are shared between central city and suburban dwellers, as the urban and suburban areas grow (or decline) together. In the case of a top-level sports franchise, the suggestion that cooperative efforts between the urban and suburban areas are likely to yield the best outcome for the region should result in cost sharing agreements, yet in practice, it is difficult to convince suburbs to bear, at least partially, any of the development costs. In Oklahoma City, voters within the city agreed to the continued $1 \%$ sales tax premium without explicit participation from nearby suburbs. Suburban residents contributed to the funding efforts only to the extent that local market conditions allowed for the tax to be successfully exported.

Studies examining the economic impact of hosting athletic events and franchises admit that the impact is generally negative to neutral, with a few exceptions worth noting. Coates and Humphreys (1999) find an overall negative effect on per capita income from supporting professional sports franchises in 37 MSAs from 1969 through 1994. Hudson (1999) examines 17 US cities for employment effects from professional franchises in those cities, but finds none. Matheson (2005) examines personal income growth in cities with Super Bowl champion teams and finds no evidence of a positive effect. Lertwachara and Cochran (2007) use an event study approach to examine the effect of relocation and expansion of professional sports teams on MSA per capita income and growth rates of per capita income. They find that professional sport franchises reduce MSA per capita income. Propheter (2012) examines 24 NBA host cities and finds only scant evidence of a positive effect on personal income from building NBA arenas.

Conversely, Davis and End (2010) find that winning NFL teams increase local 
per capita GDP. Coates and Humphreys (2003) find both positive and negative wage effects for cities hosting professional franchises estimating the net effect to be neutral and interpret the finding as evidence of household's substituting in consumption. Carlino and Coulson (2004) show that wages are lower in franchise cities, though not statistically significant, while rents are significantly higher. Coates, Humphreys, and Zimbalist (2006), in a rejoinder, find that the Carlino and Coulson results are not robust to model specifications. Coates and Humphreys (2011) admit that there are some positive effects on wages for NFL hosting cities, but the results are confined to announcers, athletes and others employed in recreation.

A subset of papers focus more narrowly on the fiscal impacts of sporting events and franchises. Coates (2006) examine the effect of the Super Bowl and the MLB All-star game on Houston sales tax revenues and find positive and significant effects. Coates and Depken (2009) examine 4 mid-sized Texas cities and the effect that college football games had on sales tax revenues in those cities, finding mixed effects, but generally negative and dependent on the opponent in each game. Extending their 2009 paper, Coates and Depken (2011) examine Texas sales tax revenue responses to hosting college and professional sports. They find, in many cases, negative effects on sales tax revenues, with positive effects limited to college football towns and the Super Bowl. Finally, Somerville \& Wetzel (2010) find that there was no effect on the residential property tax base from hosting the Olympics in Vancouver.

For the purposes of this paper, the most directly comparable work is Baade, Baumann, \& Matheson, (2008). Within the work, they examine the impacts to taxable sales in Florida counties from hosting a variety of one-time major sporting events and building/improving the venues necessary to accommodate them. In virtually all cases neutral to negative effects were found. In a subsequent paper Baade and Matheson (2011) discuss the quality of life justification directly, stating that while there is evidence in support of the quality of life argument, the significance of the quality of life benefit may be appropriate for public/private development partnerships but inappropriate for $100 \%$ public subsidization. Where previous research investigated the impacts of hosting one-time events across a series of cities, this paper modifies the strategy by investigating a series of one-time events hosted in a single city.

The quality of life literature provides some guidance in considering the growth effects of local franchises. Local quality of life measures were pioneered by Roback (1982) who looks specifically at local amenity and productivity effects using hedonic estimates of willingness to pay for local amenities. Initial research included naturally occurring amenities leading to questions of whether localities' long run 
equilibrium condition rested only with the uncontrollable forces of Mother Nature. Gyourko and Tracy (1991) add local fiscal conditions to the mix and find that manmade factors could influence long-run outcomes for municipalities. Later research by Glaeser et al (2001) finds that not only is urban density good for productivity growth, it is also vital for the creation of consumer amenities which are directly correlated with population growth, as discovered by Ciccone and Hall (1996). Rappaport (2009) studied the migration-induced effects of local amenities and concludes that amenities are the sole determinant of population density asymptotically and that the population densities of cities with identical amenities but different productivity levels eventually converged. Noll \& Willner (2003) provide evidence of a positive role for professional franchises in the quality of city life.

In this paper we examine changes in the Oklahoma City sales tax revenue growth rates from hosting a series of "one-time" Thunder events and finding no evidence of a contemporaneous effect on year-over-year growth rates but modest evidence in support of a longer run, amenity growth effect.

\section{$\overline{\text { DATA }}$}

Monthly gross sales tax receipts were provided by the City of Oklahoma City. The data in levels exhibits a unit root indicating a nonstationary time series. Accordingly, the monthly data is converted into year-over-year growth rates for the January 2002 - June 2014 period.

A little more than half of the observations occur in the pre-Thunder period. The potential amenity effect is represented by a Thunder binary variable that takes the value of 1 from November 2008, the Thunder's inaugural season in Oklahoma City. The Thunder has experienced both deep playoff runs and disappointing season finishes outside the eighth and final playoff position. This reality provides richness in the dataset as many months are characterized by significantly more (or less) home games than the same month of the previous year. The difference between the number of home games played in a month relative to the same month of the previous year serves effectively as a series of "one-time" hosted events. If a contemporaneous effect on monthly sales tax receipts (as measured in year-over-year growth rates) exists, we expect to see it in the differential number of home games variable. Yearover-year differentials in the number of away games is also captured and reported.

A vector of regional economic control variables is included in the model to capture fluctuations in city economic conditions. The preferred model specification includes economic control variables on the annualized change in Oklahoma City 
MSA nonfarm employment, a U.S. recession dummy variable, and the annualized change in statewide active rig counts (a proxy for expansion or contraction in the state's primary oil and gas industry). This parsimonious control vector minimizes concerns of correlated explanatory control variables. Alternative specifications are reported for other economic controls, including measures of year-over-year growth in Oklahoma personal income and year-over-year growth in crude oil and natural gas spot prices for the months under study. All time-series data are stationary in their transformations. The tax rate is unchanged over the entire set of observations. The model results are robust to alternative specifications of the macroeconomic control vector. Finally, a time trend is included in all models. A summary of all model variables is provided in table 1 .

\begin{tabular}{|c|c|c|c|c|}
\hline \multicolumn{5}{|c|}{$\begin{array}{c}\text { Table } 1 \\
\text { Variables }\end{array}$} \\
\hline Variable & Definition & Mean & Std. Dev. & $\mathbf{N}$ \\
\hline $\begin{array}{l}\text { Growth rate aggregate } \\
\text { collections }\end{array}$ & $\begin{array}{l}\text { Annual growth rate in Total sales } \\
\text { tax revenue per month }\end{array}$ & 0.047 & 0.075 & 149 \\
\hline Thunder 1 & $\begin{array}{l}\text { Binary: } 1 \text { for each month from } \\
\text { November } 2008 \text { forward, } 0 \\
\text { otherwise }\end{array}$ & 0.421 & 0.495 & 164 \\
\hline Change in home games & $\begin{array}{l}\text { Year-to-Year difference in the } \\
\text { number of home games played } \\
\text { by the Thunder }\end{array}$ & 0.315 & 2.159 & 149 \\
\hline Change in away games & $\begin{array}{l}\text { Year-to-Year difference in the } \\
\text { number of home away played by } \\
\text { the Thunder }\end{array}$ & 0.309 & 1.989 & 149 \\
\hline Change in nonfarm employment & $\begin{array}{l}\text { Year-to-Year difference in the } \\
\text { number of non-farm employees } \\
\text { in Oklahoma City }\end{array}$ & 4.950 & 10.624 & 149 \\
\hline Recession1 & $\begin{array}{l}\text { Binary: } 1 \text { for each month of a } \\
\text { national recession, } 0 \text { otherwise }\end{array}$ & 0.171 & 0.377 & 164 \\
\hline Change in active rig counts & $\begin{array}{l}\text { Year-to-Year difference in the } \\
\text { number of oil and gas drilling } \\
\text { rigs operating in Oklahoma }\end{array}$ & 3.453 & 44.763 & 148 \\
\hline $\begin{array}{l}\text { Growth rate state personal } \\
\text { income }\end{array}$ & $\begin{array}{l}\text { Annual growth rate in Oklahoma } \\
\text { nominal Personal income, per } \\
\text { month }\end{array}$ & 0.051 & 0.045 & 165 \\
\hline Growth rate crude oil spot price & $\begin{array}{l}\text { Annual growth rate in West } \\
\text { Texas Intermediate Crude Oil } \\
\text { price, per month }\end{array}$ & 0.143 & 0.322 & 165 \\
\hline $\begin{array}{l}\text { Growth rate natural gas spot } \\
\text { price }\end{array}$ & $\begin{array}{l}\text { Annual growth rate in Henry Hub } \\
\text { Natural Gas Spot price, per } \\
\text { month }\end{array}$ & 0.137 & 0.549 & 165 \\
\hline
\end{tabular}




\section{ANALYSIS}

Year-over-year growth rates of aggregate tax collections are modeled as a function of regional economic activity, a time trend, a Thunder amenity effect, and fluctuations in the number of home and away games played. Tax rates, generally a component of revenue models, were unchanged over the entire observation period and are therefore omitted from our analysis.

Using a General Linear Model we estimate the following model:

GR Agg Collections t

$$
\begin{aligned}
& =\alpha+\beta_{1} * \text { Thunder }+\beta_{2} *\left(\text { Home }_{t}-\text { Home }_{t-12}\right)+\beta_{3} \\
& *\left(\text { Away }_{t}-\text { Away }_{t-12}\right)+\sum_{i}^{n} \gamma_{j} * X_{t}+t+\varepsilon_{t}
\end{aligned}
$$

A positive fiscal impact attributable to the presence and operations of the Thunder franchise would be expected to manifest in either or both of the coefficients on the Thunder presence and change in home games played being reported as positive and statistically significant. The primary purpose of the investigation is the influence of a change in the number of home games - the one-time events for that month but, also of interest, is a secondary investigation of the potential amenity effect captured by the Thunder presence binary indicator.

\section{RESULTS AND DISCUSSION}

The results are reported in table 2 with nine alternative specifications of the macroeconomic control vector. Across all models, the Thunder presence variable is positive and statistically significant, but may be overstated as a result of lingering serial correlation. This finding is consistent with the anecdotal evidence that the arrival of the Thunder as a permanent Oklahoma City franchise is correlated with a rapid development of the city's core as both businesses and residents return to the city center. We acknowledge that it is difficult to interpret the magnitude of the estimated amenity effect, but our findings suggest we cannot dismiss the notion that a professional sports franchise can be an important component of the urban amenity complex and a catalyst for encouraging density.

Of course, our findings are not necessarily portable to other locales. It may be that the amenity effects are concentrated in the city's first franchise, where the franchise is most likely to be a significant component of the urban amenity portfolio, while diminishing returns exist to expansions into subsequent franchises. Similarly, 
the amenity returns to Oklahoma City may be exaggerated by its economic geography. Oklahoma City is one of the largest major metropolitan areas in the nation as measured by area (square miles). In terms of area, Oklahoma City is roughly the size of Houston (about 600 miles2) and considerably larger than Dallas, Chicago, or San Diego. As such, Oklahoma City is historically one of the least dense metropolitan areas and conceivably was poised to benefit disproportionately from the productivity and agglomeration benefits associated with increased density. It is possible that the amenity effect is manifest through increased population growth rates generally or expedited urbanization of the city's core. Finally, it should be noted explicitly that our findings do not necessarily imply the optimality of public support for a professional sports franchise as there are potentially other public investment and infrastructure projects that could have impacted the urban amenity portfolio similarly.

In contrast to the positive and statistically significant amenity effect, we find no evidence of a contemporaneous impact on city sales tax collections. Across all models, playing more home games in a given month relative to the same month in the previous year does not appear to have a positive effect on year-over-year collections growth. This result is consistent with the literature on consumption substitution that concludes one-time events merely shift expenditures from one activity to another with no net increase in aggregate taxable activity. In our dataset, the months with the greatest change in home games played are the result of making a deep playoff run. For example, in the Thunder's second year the team secured the eighth and final playoff spot and faced the would-be champions that year, the Los Angeles Lakers. The Thunder lost the series in six games, but in the process secured three additional home games in Oklahoma City that were not part of the economic landscape the previous May. If a contemporaneous effect existed, we would expect to find it in this one-time event of hosting three NBA playoff games. However, purchase of playoff tickets is not a taxable sale. Therefore purchases of playoff tickets may actually be a substitution in discretionary spending away from taxable activities and towards a nontaxable activity. In addition to variations caused by playoff performance, our dataset also captures the effects of the 2011 NBA lockout. The combination of playoff performance and the lockout provides ample opportunity to find a contemporaneous effect if it existed in the dataset. 


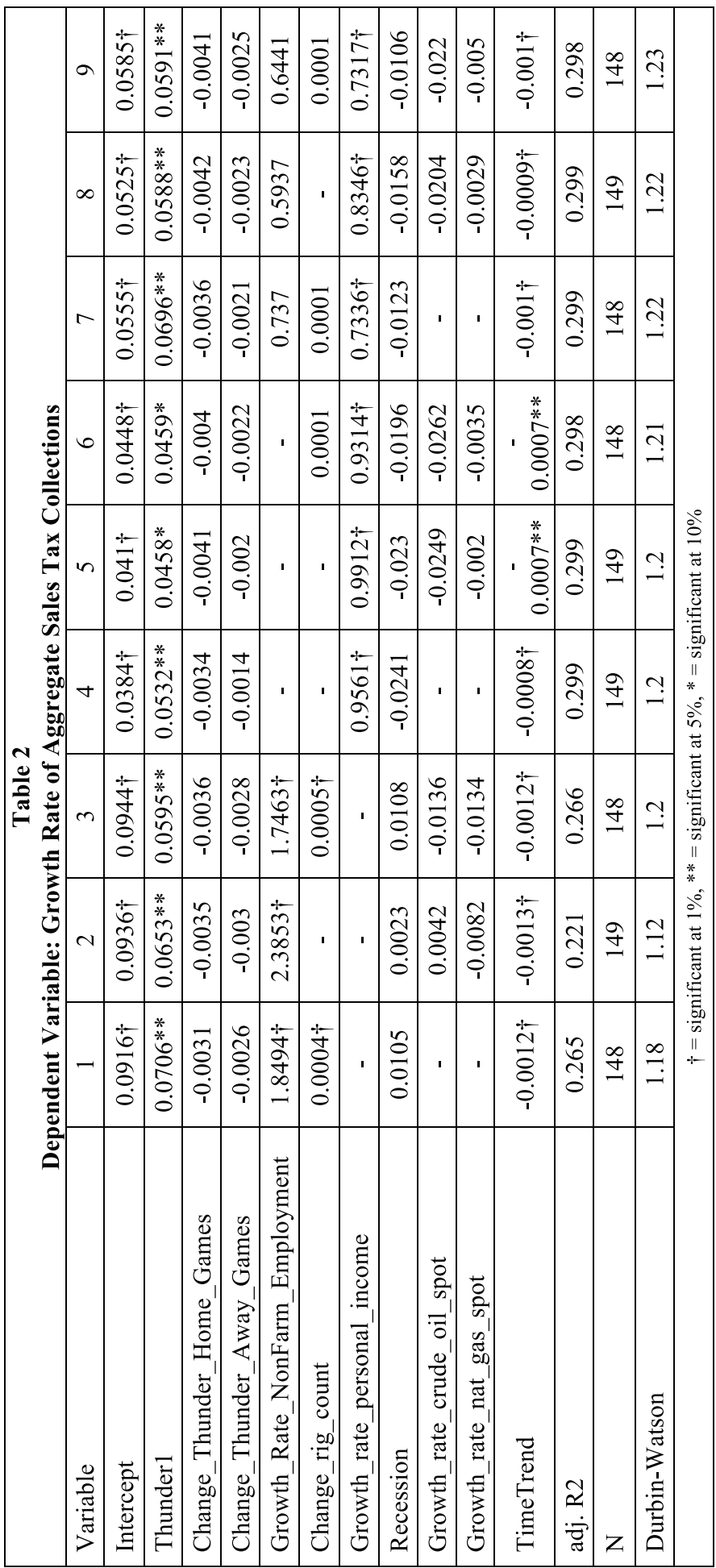




\section{CONCLUSION}

It often seems that economic development agents support the economic benefits of professional sport franchises with an enthusiasm that is only matched by the passion with which economists dismiss them. Perhaps the truth lies somewhere in the middle and benefits from case-specific rather than generalized analysis. We investigate the case of Oklahoma City, examining specifically the municipal fiscal impacts of the city's first and only major professional franchise. We find no evidence that the variation in the number of home games played has a statistically significant effect on sales tax growth. However, we do find some evidence of an amenity level effect, suggesting the franchise is an important component of Oklahoma City's developing urban amenity portfolio.

\section{REFERENCES}

Baade, Robert A., \& Matheson, Victor A. (2011). "Financing Professional Sports Facilities." College of Holy Cross, Department of Economics Faculty Research Series, Paper No. 11-02 n.d.

Baade, Robert A., Baumann, Robert \& Matheson, Victor A. (2008). "Selling the Game: Estimating the Economic Impact of Professional Sports through Taxable Sales." Southern Economic Journal 74, no. 3: 794-810.

Bryant, Brent and Evans, Monty. (2007, May). "New Orleans/Oklahoma City Hornets Economic Impact, City of Oklahoma City-Revised Analysis." Oklahoma Capital Investments Board.

Carlino, Gerald, and Coulson, N. Edward. (2004). "Compensating Differentials and the Social Benefits of the NFL." Journal of Urban Economics 56, no. 1: 25-50. Ciccone, Antonio, and Hall, Robert E. (1996). "Productivity and the Density of

Economic Activity." American Economic Review 86, no. 1: 54-70.

Coates, Dennis. (2007, October). "Stadiums and Arenas: Economic Development or Economic Redistribution.” Contemporary Economic Policy 25, no. 4: 565-577. Coates, Dennis. (2006). "The Tax Benefits of Hosting the Super Bowl and the MLB All-Star Game: The Houston Experience." International Journal of Sport Finance 1, no. 4: 239-252.

Coates, Dennis, and Humphreys, Bard R. (2008). "Do Economists Reach a Conclusion on Subsidies for Sports Franchiese, Stadiums and Mega-events?" Econ Journal Watch 5, no. 3: 294-315. 
Coates, Dennis, \& Brad R Humphreys. (2011). "The Effect of Professional Sports on the Earnings of Individuals: Evidence from Microeconomic Data." Applied Economics 43, no. 29: 28-30.

Coates, Dennis, and Humphreys, Brad R. (2008). "Do Economists Reach a Conclusion on Subsidies for Sports Franchiese, Stadiums and Mega-events?" Econ Journal Watch 5, no. 3: 294-315.

Coates, Dennis, and Humphreys, Brad R. (2003). "The effect of professional sports on earnings and employment in the services and retail sectors in US cities." Terional Science and Urban Economics 33: 175-198.

Coates, Dennis, and Humphreys, Brad R. (2011). "The Effect of Professional Sports on the Earnings of Individuals: Evidence from Microeconomic Data." Applied Economics 43: 28-30.

Coates, Dennis, and Humphreys, Brad R. (1999). "The Growth Effects of Sport Franchises, Stadia and Arenas." Journal of Policy Analysis and Management 18, no. 4: 601-624.

Coates, Dennis, and Depken, Craig A. (2011). "Mega-events: Is Baylor Football to Waco What the Super Bowl is to Houston?" Journal of Sports Economics 12, no. 6: 599-620.

Coates, Dennis, and Depkin, Craig A. (2009). "The Impact of College Football Games on Local Sales Tax Revenue: Evidence from Four Cities in Texas." Eastern Economic Journal 35, no. 4: 531-547.

Coates, Dennis, Humphreys, Brad R., \& Zimbalist, Andrew. (2006). "Compensating Differentials and the Social Benefits of the NFL: A Comment." Journal of Urban Economics 60, no. 1: 124-31.

Davis, Michael C., and End, Christian M. (2010). "A Winning Proposition: The Economic Impact of Successful National Fottball League Franchises." Economic Inquiry 48, no. 1: 39-50.

Glaeser, E. L., Kolko, J., \& Saiz, A. (2001). “Consumer City.” Journal of Economic Geography 1, no. 1 (2001): 27-50.

Gyourko, J., and Tracy, J. (1991). "The Structure of Local Public Finance and the Quality of Life." Journal of Political Economy 99, no. 4: 774-806.

Haughwout, A. F. and Inman, R. P. (2002). Should Suburbs Help Their Central City: Brookings-Wharton Papers on Urban Affairs.

Helman, Christopher. (2012, June). "The Sordid Deal That Created the Oklahoma City Thunder.” Forbes.com.

Hudson, Ian. (1999). "Bright Lights, Big City: Do Professional Sports Teams Increase Employment?" Journal of Urban Affairs 21, no. 4: 397-407. 
Johnson, Bruce K., Groothuis, Peter A., \& Whitehead, John C. (2001, February). "The Value of Public Goods Generated by a Major League Sports Team: The CVM Approach." Journal of Sports Economics 2, no. 1: 6-21.

Lavoie, Marc, and Rodriguez, Gabriel. (2005). "The Economic Impact of Proressional Teams on Monthly Hotel Occupacny Rates of Canadian Cities: A Box-Jenkins Approach." Journal of Sports Economics 6, no. 3: 314-324.

Lertwachara, Kaveephong, and Cochran, James J. (2007). "An Event Study of the Economic Impact of Professional Sport Franchises on Local U.S. Economies." Jounral of Sports Economics 8, no. 3: 244-54.

Matheson, Victor A. (2005). "Contrary Evidence on the Economic Effect of the Super Bowl on the Victorious City." Journal of Sports Economics 6, no. 4: 420428.

McGregor, P. G., Swales, J. K., \& Yin, Y. P. (1996). "A Long-Run Interpretaion of Regional Input-Output Analysis." Journal of Regional Scinece 36, no. 3: 479500 .

Nelson, Arthur C. (2001). "Prosperity of Blight? A Question of Major Lague Stadia Locations." Economic Development Quarterly 15, no. 3: 255-265.

Noll, Dennis, and Willner, Jonathan. (2003). "Professional Sports and the Quality of

City Life." Southwestern Journal of Economics 5, no. 2: 133-153.

Noll, Roger G. and Zimbalist, Andrew. (1997). Sports, Jobs and Taxes: The Economic Impact of Sports Teams and Stadiums. Brookings Institute Press.

Porter, Philip K. (2001). Mega-Sports Events as Municipal Investments: A Critique of Impact Analysis. Vol. 2, in The Economics of Sport, by Andrew Zimbalist, 370-283. Edward Elgar.

Propheter, Geoffrey. (2012). "Are Basketball Arenas Catalysts of Economic Development?" Journal of Urban Affairs 34, no. 4: 441-459.

Rappaport, J. (2009).’The Increasing Importance of Quality of Life." Journal of Economic Geography 9, no. 6: 779-804.

Rappaport, J. (2005)."The Shared Fortunes of Cities and Suburbs." Economic Review 90, no. 3: 33-60.

Rappaport, Jordan and Wilkerson, Chad. (2001). "What Are the Benefits of Hosting a Major League Sports Franchise?" Economic Review (Federal Reserve Bank of Kansas City), First Quarter: 55-91.

Roback, J. "Wages, Rents and the Quality of Life." Journal of Political Economy 90, no. 6 (1982): 1257-1278. 
Siegfried, John, and Zimbalist, Andrew. (2006). "The Economic Impact of Sports Facilities, Teams and Mega-Events." Austalian Economic Review 39, no. 4: 420-7.

Siegfried, John, and Zimbalist, Andrew. (2000). “The Economics of Sports Facilities and Their Communities." Journal of Economic Perspectives 14, no. 3: 95-114. Somerville, Tsur, and Wetzel, Jake. (2010). "Hunting for the Olympics Bounce:

Any Evidence in Real Estate?" Centre for Urban Economics and Real Estate, Discussion Paper 2010-01, University of British Columbia.

Zaretsky, Adam M. (2001, April). "Should Cities Pay for Sports Facilities." The Regional Economist (Federal Reserve Bank of St. Louis): 5-9.

\section{BIOGRAPHICAL SKETCH OF AUTHORS}

Kyle Dean is the Associate Director, Steven C. Agee Economic Research \& Policy Institute and an Assistant Prof. of Economics in the Meinders School of Business, Oklahoma City University. He holds a Ph.D. in Economics from Oklahoma State University. Dr. Dean began consulting in 2005 and his client list includes some of Oklahoma's most influential businesses and trade associations, including the Oklahoma Independent Producers Association (OIPA), the Oklahoma Bankers' Association (OBA), the Oklahoma Telephone Association (OTA) and many others. He is best known for his comprehensive work with Oklahoma tribes, having completed the first ever estimate of the combined economic impacts from Oklahoma tribal activities.

Russell Evans is the Executive Director of the Steven C. Agee Economic Research and Policy Institute (ERPI), Director of the Center for Regional Economic Forecasting and Policy Analysis, and Assistant Professor of Economics. and Assistant Professor of Economics in the Meinders School of Business, Oklahoma City University. He holds a Ph.D. in Economics from Oklahoma State University. $\mathrm{He}$ is a Co-Founder Principal of the Economic Impact Group, LLC. As the Executive Director of ERPI he is involved in developing relationships with the business community and directing funded research projects. Dr. Evans' research involves issues important to local civic leaders including the economic and fiscal outlook for the OKC economy, the Oklahoma Consumer Sentiment Index, the Oklahoma Energy Index, and the economic impact of the state's primary industries including oil and gas and Native American operations.

Jonathan Willner is the B.C. Clark Jr. Chair in Economics and Professor of Economics in the Meinders School of Business, Oklahoma City University. Dr. 
Willner specializes in three main areas: sports economics, international trade, and industrial organization. Additional areas of expertise are those related to intellectual property rights and natural disasters. His research in sports economics deals with the economic impacts of the Olympics and U.S. major league franchises. His industrial organization research deals with conglomerate effects in Korea as well as domestic issues associated with legal structures. He teaches courses in a variety of fields including international economics and game theory. 